\title{
Catheter-associated urinary tract infection in patients treated for acute urinary retention is common.
}

Ben Butcher, Sharon Klim, Anne-Maree Kelly

Acute urinary retention (AUR) is a relatively common presentation to Emergency

Departments (EDs). Standard management is insertion of a urethral catheter. In some hospitals, patients are discharged to ambulatory care with view to an outpatient trial of void sometime in the future. Urinary tract infection (UTI) is a well-recognized complication of urethral catheterization. Bacteriuria in patients with indwelling bladder catheters occurs at a rate of approximately $3-10 \%$ per day of catheterization $[1,2]$. Of those with bacteriuria, $10-$ $25 \%$ percent develop symptoms of catheter-associated UTI (CAUTI). [3-5]. There is a paucity of information on the rate of CAUTI in the ED population treated acutely for AUR.

We undertook a prospective observational study with telephone follow-up. We included all adult male patients who presented to the ED of one of two community teaching hospital ED in AUR, who are catheterized by ED staff and then discharged for outpatient follow-up. We excluded patients aged under 18, female patients, patients requiring hospital admission, patients with established urinary tract infection at the time of index presentation, complicated catheterization requiring guidewire/cystoscopy by urology team, patients with chronic urinary retention requiring attention to or replacement of an existing catheter, inability to communicate in English, absence of patient contact details and patients who declined consent. The project was approved by the Western Health Low Risk Ethics Panel as a quality assurance project.

Two hundred and seventy six patients were screened for inclusion of whom 49 were eligible. The largest exclusion criteria was established UTI at index ED visit. Median age was 70 (IQR $63-78), 27 \%$ had had a surgical procedure in the week prior to the index visit $(95 \% \mathrm{Cl}$ $15-41 \%)$ and median total duration of catheterization was 15 days (IQR 9-21). Twenty-nine percent $(95 \% \mathrm{Cl} 17-43 \%)$ were prescribed antibiotics for a clinically diagnosed CAUTI at a median catheter duration of 12 days (IQR 7-26). Ten percent of patients were hospitalized with CAUTI (95\% Cl 4-23\%). We did not detect an association between duration of catheterization and CAUTI however our sample was under-powered to do so.

This is the author manuscript accepted for publication and has undergone full peer review but has not been through the copyediting, typesetting, pagination and proofreading process, which may lead to differences between this version and the Version of Record. Please cite this article as doi: $10.1111 / 1742-6723.12914$

This article is protected by copyright. All rights reserved. 
Our results suggest that the occurrence of CAUTI is common in patients catheterized in ED for AUR. This has important implications for processes in ED and for patient education. ED processes need to ensure that appropriate aseptic technique is followed at catheter insertion. Patient education needs to cover personal hygiene, general catheter care and catheter emptying procedures to minimise contamination as well as warning of the symptoms of CAUTI and when to see medical care. Written materials to reinforce important points may help retention of information.[6] In our experience, patient education is often rushed, unstructured, incomplete and not supported by written materials in an appropriate language.

In conclusion, the rate of CAUTI for ED-inserted urinary catheters for AUR is high. Measures to improve this include attention to ED processes and patient education.

\section{References}

1. Warren JW, Platt R, Thomas RJ, et al. Antibiotic irrigation and catheter-associated urinary-tract infections. N Engl J Med 1978; 299:570.

2. Haley RW, Hooton TM, Culver DH, et al. Nosocomial infections in U.S. hospitals, 19751976: estimated frequency by selected characteristics of patients. Am J Med 1981; 70:947.

3. Tambyah PA, Maki DG. Catheter-associated urinary tract infection is rarely symptomatic: a prospective study of 1,497 catheterized patients. Arch Intern Med 2000; 160:678.

4. Saint S. Clinical and economic consequences of nosocomial catheter-related bacteriuria. Am J Infect Control 2000; 28:68.

5. Leuck AM, Wright D, Ellingson L, et al. Complications of Foley catheters--is infection the greatest risk? J Urol 2012; 187:1662.

6. New South Wales Health. Caring for your catheter at home. http://www.seslhd.health.nsw.gov.au/Carer_Support_Program/Documents/CATHETER\% 20PK.pdf. Accessed 25 October 2017.

This article is protected by copyright. All rights reserved. 


\section{University Library}

\section{- M M N E R VA A gateway to Melbourne's research publications}

Minerva Access is the Institutional Repository of The University of Melbourne

Author/s:

Butcher, B;Klim, S;Kelly, A-M

Title:

Catheter-associated urinary tract infection in patients treated for acute urinary retention is common

Date:

2018-02-01

Citation:

Butcher, B., Klim, S. \& Kelly, A. -M. (2018). Catheter-associated urinary tract infection in patients treated for acute urinary retention is common. EMERGENCY MEDICINE AUSTRALASIA, 30 (1), pp.135-136. https://doi.org/10.1111/1742-6723.12914.

Persistent Link:

http://hdl.handle.net/11343/293985 